\title{
Fitoremediasi Menggunakan Variasi Kombinasi Tanaman Kiambang (Salvinia Molesta M) dan Tanaman Kayu Apu (Pistia Stratiotes L) dalam Menurunkan Besi (Fe) dengan Sistem Batch
}

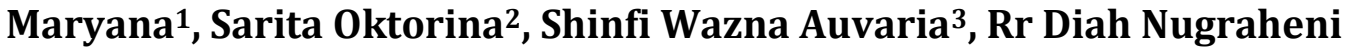 \\ Setyowati ${ }^{4}$ \\ 1,2,3,4Universitas Islam Negeri Sunan Ampel, Surabaya, Indonesia \\ Meriana820@gmail.com ${ }^{1}$
}

\begin{abstract}
The increased industrial development can cause pollution and environmental damage. Iron metal is an essential metal whose existence is a certain amount needed by living organisms, but in excessive amounts will cause toxic effects. To overcome this problem, an environmentally friendly technology is needed, namely phytoremediation technology using kiambang plants (Salvinia molesta M) and Kayu apu plants (Pistia stratiotes $L$ ). The purpose of this study was to determine the efficiency of reducing the concentration of iron ( $\mathrm{Fe}$ ) in ground water using a combination of kiambang (Salvinia molesta $M$ ) and a combination of Kayu apu plants (Pistia stratiotes $L$ ). This research method is experimental and the research approach used is qualitative analysis. The process of phytoremediation with a batch system using a Kiambang plant (Salvinia molesta M) and wooden apu (Pistia stratiotes L) as much as 300 grams (uses a variation of the amount different from the same weight (25:75) (150:150) (75:25)) in each reactor. The results showed a decline on the 12th day. In the reactor treatment group of 1 is $0.30 \mathrm{mg} / \mathrm{l}$ and efficiency at $47 \%$, reactor 2 is $0.06 \mathrm{mg} / \mathrm{l}$ and efficiency of $93 \%$, and reactor 3 is $0.49 \mathrm{mg} / \mathrm{l}$ and efficiency of $9 \%$. The highest efficiency value in decreasing the concentration of iron $(\mathrm{Fe})$ in groundwater using variations in the combination of Kiambang plant (Salvinia molesta M) and the wooded plant (Pistia stratiotes L) in the reactor treatment group 2 is $93 \%$ on the 12 th day.
\end{abstract}

Keywords: Iron (Fe), Groundwater, Phytoremediation, Salvinia molesta M, Pistia stratiotes L

\begin{abstract}
Abstrak
Meningkatnya pembangunan industri dapat menyebabkan pencemaran dan kerusakan lingkungan. Logam berat besi adalah logam esensial yang keberadaannya dalam jumlah tertentu sangat dibutuhkan organisme hidup, namun dalam jumlah yang banyak dapat menyebabkan racun. Untuk mengatasi permasalahan tersebut maka diperlukan sebuah teknologi yang ramah lingkungan yakni dengan teknologi fitoremediasi menggunakan tanaman kiambang (Salvinia molesta.M) dan tanaman kayu apu (Pistia stratiotes L). Tujuan penelitian ini adalah mengetahui efesiensi penurunan konsentrasi besi pada air tanah menggunakan variasi kombinasi tanaman kiambang (Salvinia molesta M) dan tanaman kayu apu (Pistia stratiotes L). Metode penelitian ini bersifat eksperimental dan pendekatan penelitian yang digunakan adalah analisa kualitatif. Proses fitoremediasi dengan sistem batch menggunakan tanaman kiambang (Salvinia molesta M) dan tanaman kayu apu (Pistia stratiotes L) sebanyak 300 gram (menggunakan variasi jumlah berbeda dengan berat yang sama yaitu (25:75) (150:150) (75:25)) pada setiap reaktor. Hasil penelitian menunjukkan terjadinya penurunanan pada hari ke-12. Pada kelompok perlakuan reaktor 1 yaitu 0,30 $\mathrm{mg} / \mathrm{l}$ dan efisiensi sebesar $47 \%$, reaktor 2 yaitu $0,06 \mathrm{mg} / \mathrm{l}$ dan efisiensi sebesar $93 \%$, dan reaktor 3 yaitu $0,49 \mathrm{mg} / \mathrm{l}$ dan efisiensi sebesar $9 \%$. Nilai efisiensi tertinggi pada penurunan konsentrasi Besi (Fe) pada air tanah menggunakan variasi kombinasi tanaman kiambang (Salvinia molesta M) dan tanaman kayu apu (Pistia stratiotes $L$ ) terdapat pada reaktor 2 yaitu sebesar $93 \%$ pada harri ke- 12 .
\end{abstract}

Kata Kunci: Besi (Fe), Air tanah, Fitoremediasi, Salvinia molesta M, Pistia stratiotes L 


\section{PENDAHULUAN}

Kebutuhan air yang digunakan di Indonesia berasal dari sumber mata air dan sungai. Berdasarkan pemantauan dari Kementrian Lingkungan Hidup Republik Indonesia tahun 2014 sebanyak 75\% air sungai mengalami pencemaran berat yang di sebabkan oleh buangan air limbah rumah tangga seperti deterjen dan logam berat. Logam berat yang digunakan pada penelitian ini adalah besi ( Fe), karena besi ( Fe) masih sering dijumpai dalam air permukaan maupun air tanah. Untuk menurunkan kandungan logam berat besi (Fe) pada air terdapat beberapa cara alternatif diantaranya seperti, proses aerasi - filtrasi, khlorinasi - filtrasi, kalium permagganat filtrasi dengan mangan zeolit, akan tetapi metode - metode tersebut membutuhkan peralatan yang banyak dan mahal (Said, 2005). Selain metode tersebut terdapat metode lain untuk menurunkan logam berat (Fe) yaitu dengan cara fitoremediasi. Fitoremediasi merupakan teknologi yang sederhana, ramah lingkungan, murah dan tidak banyak menggunakan lahan serta dapat menyerap polutan (Yuliani, 2019)

Tanaman fitoremidiator yang digunakan pada Penelitian ini yaitu, tanaman air jenis kayu apu (Pistia stratiotes L) dan tanaman kiambag (Salvinia molesta M) Pemilihan kedua tanaman karena memiliki pertimbangan yang tinggi dari sifat hiperakumulator serta mudah dijumpai di sawah, sungai, dan rawa.
Tujuan penelitian ini untuk mengetahui efisiensi penurunan konsentrasi Besi (Fe) pada air tanah menggunakan variasi kombinasi kayu apu (Pistia stratiotes L) dan kiambang (Salvinia molesta $M$ ) serta untuk mengetahui perbedaan jumlah variasi kobinasi kedua tanaman tersebut.

\section{METODE PENELITIAN}

\section{A. Lokasi dan waktu penelitian}

Metode yang digunakan dalam menurunkan Besi (Fe) dengan sistem batch dengan skala laboratorium. Metode yang digunakan bersifat eksperimental dan pendekatan penelitian yang digunakan adalah analisa kualitatif. Penelitian ini dilaksanakan sekitar bulan maret 2020 yang berlokasi di Laboratorium UIN Sunan Ampel Surabaya.

\section{B. Alat dan Bahan Penelitian}

Peralatan yang digunakan yaitu, reaktor berbahan kaca sebanyak 4 buah dengan $\mathrm{P} x \mathrm{~L}$ $\mathrm{x} T(60 \mathrm{~cm} \times 35 \mathrm{~cm} \times 15 \mathrm{~cm})$, jerigen, $\mathrm{pH}$ meter, spektrofotometer. Bahan penelitian menggunakan air tanah didaerah Driyorejo. Selain itu menggunakan tanaman kayu apu (Pistia stratiotes L) dan kiambang (Salvinia molesta $M$ ) dengan menggunakan variasi jumlah berbeda dan berat basah sama sebanyak 300 gram pada setiap reaktor. Adapun kerangka pikir yang digunakan pada penelitian terdapat pada Gambar 1.

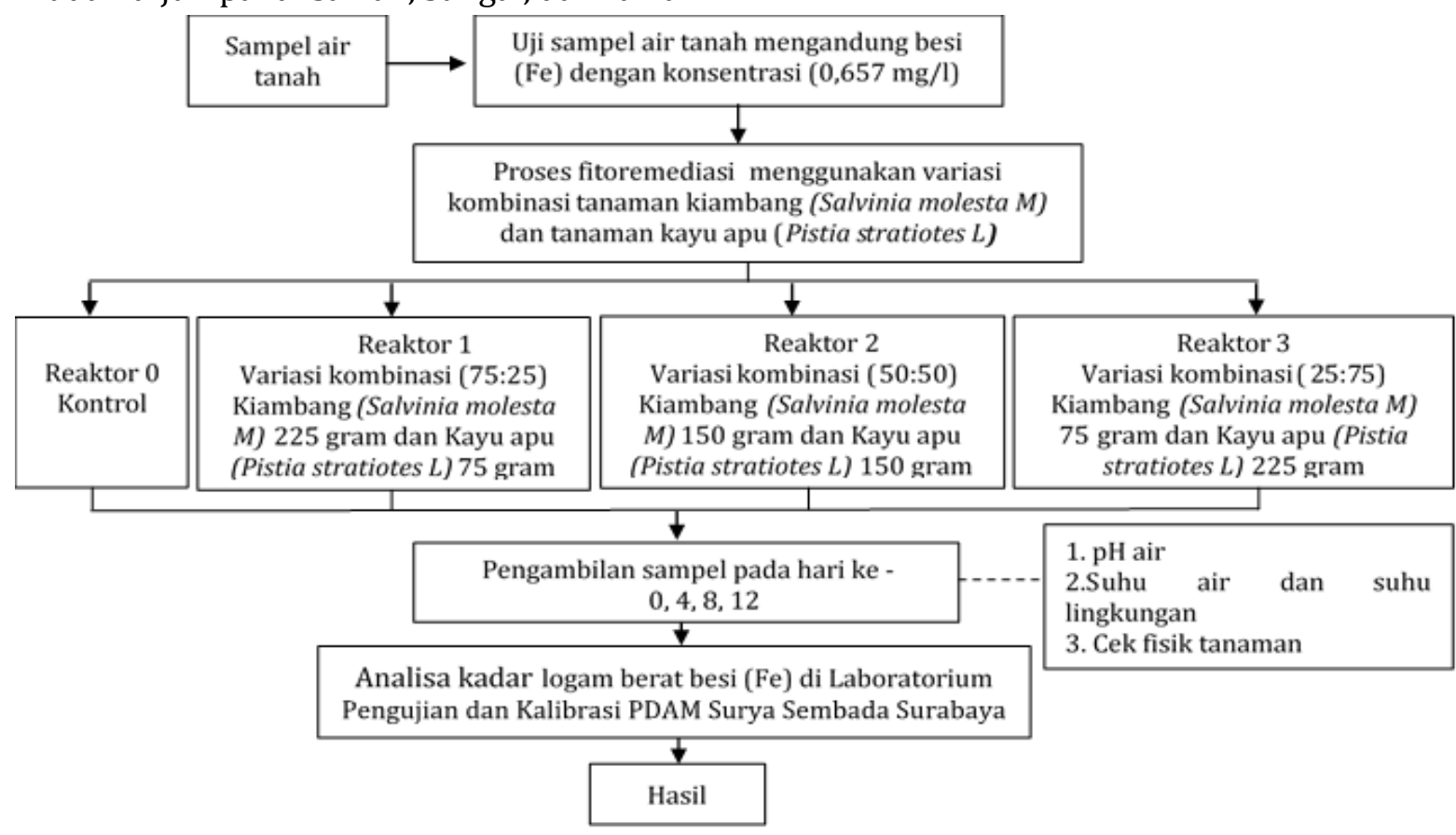

Gambar 1 Kerangka Pikir Penelitian 


\section{Metode Kerja}

Metode kerja yang digunakan adalah menggunakan air sampel jenis sumur bor produksi yang bertempat di Driyorejo. Sampel air yang digunkakan sebanyak 15 liter. Dengan alat dan bahan yang telah ditentukan. Kriteria tanaman kiambang (Salvinia molesta M) yaitu (panjang akar sekitar $6-7,5 \mathrm{~cm}$ dan daun sebanyak 17 - 45 buah). Sedangkan kriteria tanaman kayu apu (Pistia stratiotes L) yaitu (panjang akar sekitar 16 - 20,5 cm dan daun sebanyak 19 23 buah). Kedua tanaman ini diambil dari Balai Konservasi Tumbuhan Kebun Raya Purwodadi dan sebagian dari penjual tanaman di Kayoon Surabaya.

Proses aklimatisasi pada kedua tanaman yang digunakan dilakukan selama 10 hari dengan air bersih. Perlakuan pada media tanam yaitu mempersiapkan 4 reaktor yang sesuai ketentuan dan 15 liter air sumur kedalam masing - masing reaktor. Kemudian memasukkan kedua tanaman yang telah dilalukan proses aklimatisasi kedalam reaktor sesuai dengan 0 (reaktor tidak menggunakan tanaman), variasi kombinasi tanaman (75:25) dengan perbandingan kedua tanaman yaitu tanaman kiambang (Salvinia molesta M) 225 gram dan tanaman kayu apu (Pistia stratiotes $L$ ) 75 gram, variasi kombinasi (50:50) yaitu tanaman kiambang (Salvinia molesta M) 150 gram dan tanaman kayu apu (Pistia stratiotes L) 150 gram, variasi kombinasi (25:75) yaitu tanaman kiambang (Salvinia molesta M) 75 gram dan tanaman kayu apu (Pistia stratiotes L) 225 gram (Sata, 2018). Tanaman yang digunakan diseragam sesuai dengan kriteria yang telah ditentukan.

Pada penelitian ini dialukan pengambilan sampel setiap 4 hari sekali yaitu pada hari ke $0,4,8,12$ dan dilakukan analisis kandungan besi (Fe) untuk uji laboratorium. Selain dilakukan pengambilan sampel untuk uji besi (Fe) dilakukan data pendukung yaitu dengan cara melakukan analisis harian seperti pengukuran $\mathrm{pH}$ air, suhu air dan suhu lingkungan, pengecekan kondisi fisik tanaman (warna daun). Sedangkan untuk pengecekan akar tanaman dilakukan diawal dan diakhir proses fitoremediasi. Proses fitoremediasi dilakukan selama 12 hari.

\section{HASIL DAN PEMBAHASAN}

A. Kemampuan Tanaman Kayu Apu (Pistia stratiotes L) dan Kiambang (Salvinia molesta M) Terhadap Removal Besi (Fe)

Kemampuan tanaman kiambang (Salvinia molesta M) dan (Pistia stratiotes L) dalam meremoval logam berat besi (Fe) pada air tanah dapat dilihat pada Gambar 2.

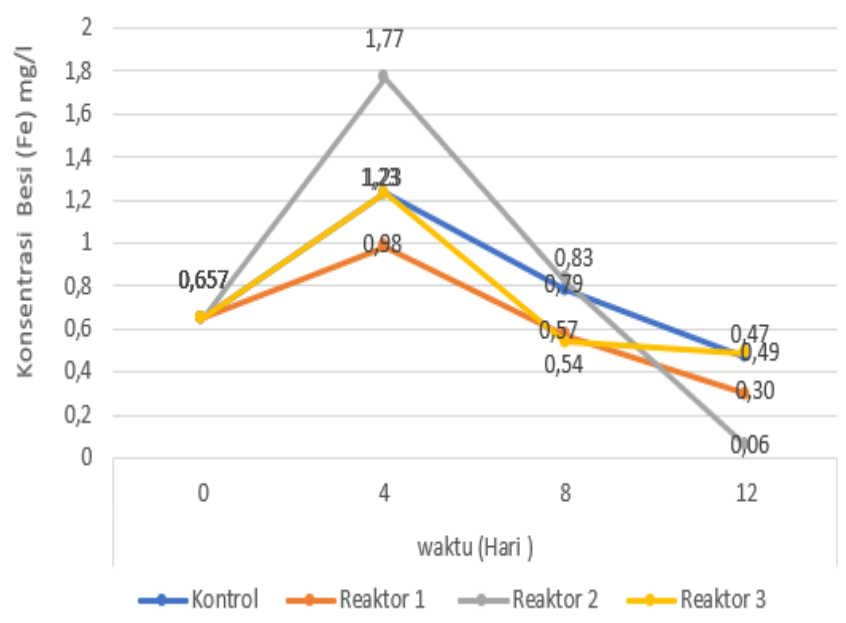

Gambar 2 Grafik Kemampuan Tanaman Kayu Apu (Pistia stratiotes L) dan Kiambang (Salvinia molesta M) terhadap Removal Besi (Fe)

Pada Gambar 2 didapatkan hasil penelitian konsentrasi besi ( $\mathrm{Fe}$ ) pada reaktor kontrol dan reaktor 1,2 dan 3 dengan menggunakan variasi kombinasi kedua tanaman. Konsentrasi besi ( $\mathrm{Fe}$ ) pada reaktor kontrol pada awal penelitian sebesar 0.657 $\mathrm{mg} / \mathrm{l}$, kemudian pada pengambilan $\mathrm{H}_{4}$ konsentrasi besi ( $\mathrm{Fe})$ mengalami kenaikan pada semua reaktor kontrol, reaktor 1,2 dan 3. Kemudian pada pengamatan yang dilakukan pengambilan $\mathrm{H}_{8}$ sampai dengan hari terakhir yaitu $\mathrm{H}_{12}$ konsentrasi besi ( $\mathrm{Fe}$ ) mengalami penurunan yang dimana konsentrasi besi ( $\mathrm{Fe})$ pada reaktor 1 sebesar $0.30 \mathrm{mg} / \mathrm{L}$, reaktor 2 sebesar $0.06 \mathrm{mg} / \mathrm{L}$ dan reaktor 3 sebesar $0.49 \mathrm{mg} / \mathrm{L}$. Berdasarkan dari penelitian yang telah dilakukan dalam menurunkan konsentrasi besi (Fe) menggunakan kedua tanaman, pada reaktor 1 dan reaktor 2 telah memenuhi baku mutu sesuai permenkes tahun 2010 akan tetapi pada reaktor 3 konsentrasi besi $(\mathrm{Fe})$ masih diatas baku mutu.

Kenaikan konsentrasi besi (Fe) bisa disebabkan karena suhu yang ada didalam reaktor dan $\mathrm{pH}$ air yang rendah (Pribadi, 
2016). Pada penelitian yang dilakukan pada hari ke-0 pH air sebesar 7,9 dan suhu $29{ }^{\circ} \mathrm{C}$, pada hari ke-4 $\mathrm{pH}$ air antara 7,7 - 8,3 dan suhu $30{ }^{\circ} \mathrm{C}$, pada hari ke-8 pH air 8,5 - 8,6 dan suhu $28{ }^{\circ} \mathrm{C}$, hari ke-12 $\mathrm{pH}$ air 8,5-8,6 dan suhu $29{ }^{\circ} \mathrm{C}$. pH air dapat mempengaruhi kesadahan besi dalam air yang mana apabila kadar besi rendah akan mengakibatkan terjadinya proses krosif sehingga besi akan larut dalam air (Supiyanti, 2015). Pada peneltian yang telah dilakukan (Bonny, 2017) menyatakan tingginya konsentrasi besi (Fe) dalam air disebabkan karena $\mathrm{pH}$ air, $\mathrm{pH}$ air $<7$ dapat melarutkan logam termasuk besi sedangkan pada $\mathrm{pH}>7$ kelarutan besi (Fe) sangat kecil. Kemudian tingginya temperatur air akan meningkatkan drajat korosif, serta adanya gas -gas $\mathrm{CO}_{2}, \mathrm{CO}_{2}$, $\mathrm{H}_{2} \mathrm{~S}$ ) yang bersifat korosif. Selain itu penyebab lain tingginya besi (Fe) karena adanya bakteri besi yang dalam hidupnya membutuhkan makanan dengan mengoksidasi besi sehingga larut. Jenis bakteri ini adalah Leptotrik, Crenotrik, Callitonella, Siderocapsa dan lainnya.

Selain itu kenaikan konsentrasi besi $(\mathrm{Fe})$ pada $\mathrm{H}_{4}$ pada reaktor 1,2 dan 3 bisa disebabkan karena kedua tanaman yang digunakan mengalami fase penyesuaian diri sehingga tanaman hanya menyerap zat pencemar yang terkandung dalam air secara berlebihan dan mengakibatkan tanaman mengalami kejenuhan sehingga penyerapan zat pencemar tidak maksimal (Rido, 2013). Terjadinya kejenuhan pada tanaman terjadi pada penelitian yang dilakukan (Nurlina, 2016) pada penurunan besi (Fe) yang dilakukan selama 14 hari. Konsentrasi besi pada hari pertama 767.75 ppm setelah mencapai hari ke 7 mengalami kenaikan, dan terjadi penurunan setelah hari ke 14 menjadi 625.36 ppm, kenaikan disebabkan karena terjadinya kejenuhan tumbuhan dalam mengakumulasi logam berat. Titik jenuh merupakan suatu batas maksimum yang dapat ditoleransi tanaman dalam menyerap kontaminan. Kejenuhan dapat terjadi karena tanaman telah menyerap sebagian zat kontaminan pada limbah yang dimana semakin banyak kontaminan yang diserap maka akan semakin banyak pula kontaminan yang terakumulasi pada jarigan tanaman, sehingga menyebabkan kejenuhan pada tanaman dan menyebabkan terlambatnya penyerapan kontaminan oleh jaringan tanaman (Arasy, 2016). Kejenuhan tanaman pada penelitian ini sesuai dengan penelitian (Nurfitriani, 2019) menyatakan kejenuhan yang terjadi pada tanaman akan mengakibatkan ketidak mampuan suatu tanaman dalam menyerap logam besi ( $\mathrm{Fe}$ ) dan melepaskan logam yang telah diserap kelingkungan. Hal serupa terjadi pada penelitian yang dilakukan (Nurfitri, 2010) terdapat beberapa titik jenuh pada tanaman, yang di mana pada hari ke 3 sebesar 0,006 $\mathrm{mg} / \mathrm{L}$ kemudian pada hari ke 5 menjadi 0,007 $\mathrm{mg} / \mathrm{L}$ dan hari ke 10 menjadi 0,009 serta terjadi penurunan di hari ke 10 .

Dari hasil pengamatan menunjukan terjadinya penurunan konsentrasi besi ( $\mathrm{Fe}$ ) pada $\mathrm{H}_{8}$ sampai hari terakhir yaitu $\mathrm{H}_{12}$. Penurunan konsentrasi besi (Fe) terjadi disemua reaktor baik reaktor kontrol dan reaktor 1, 2 dan 3. Penurunan konsentrasi besi (Fe) pada air disebabkan karena kedua tanaman yang digunakan berhasil menyisihkan kontaminan yang ada pada air dengan cara penyerapan oleh akar tanaman (Ahmadlia, 2012). Pada proses penyerapan oleh akar dibantu oleh adanya bakteri yang ada diakar tanaman yaitu rizobacter. Selain itu karena proses fotosintesis yang menghasilkan 02 yang dapat membantu proses oksidasi senyawa organik yang dapat mengikat 02 yang masuk kedalam air pada reaktor (LBN-LIPI, 1981 ) bakteri yang ada pada akar tanaman dapat mengurangi kandungan senyawa organik dan anorganik yang ada didalam air. Penelitian ini serupa dengan yang dilakukan (Bonny, 2017) menyatakan bahwa penelitian yang dilakukan selama 14 hari menggunakan 6 tanaman kayu apu (Pistia stratiotes L) mampu menurunkan kandungan besi (Fe) yang ada dalam air pada awal penelitian dengan konsentrasi 40,58 $\mathrm{mg} / \mathrm{l}$ menjadi $25,73 \mathrm{mg} / \mathrm{l}$ dihari ke 14 . Tanaman kiambang (Salvinia molesta M) memiliki kemampuan dalam penyerapam logam berat.

Pada penelitian ini terjadi perubahan fisik yang dimana perubahan tersebut merupakan respon suatu tumbuhan terhadap kontaminan yang ada dalam air hal ini merupakan kemampuan tanaman dalam beradaptasi dengan kontaminan logam berat. Perubahan fisik pada kedua tanaman seperti terjadinya kerontokan pada daun dan akar tanaman, terjadinya perubahan warna 
pada daun tanaman. Perbedaan perubahan fisik kedua tanaman pada Gambar 3
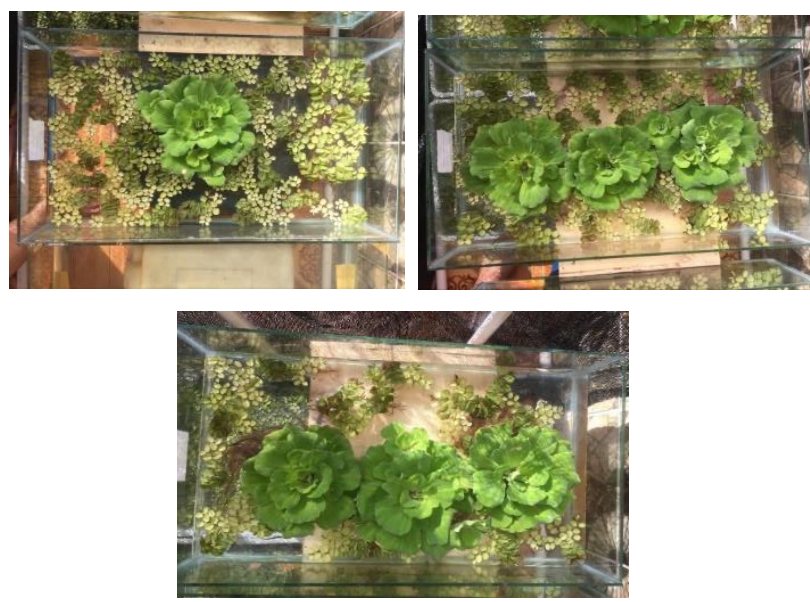

(a) Awal penelitian
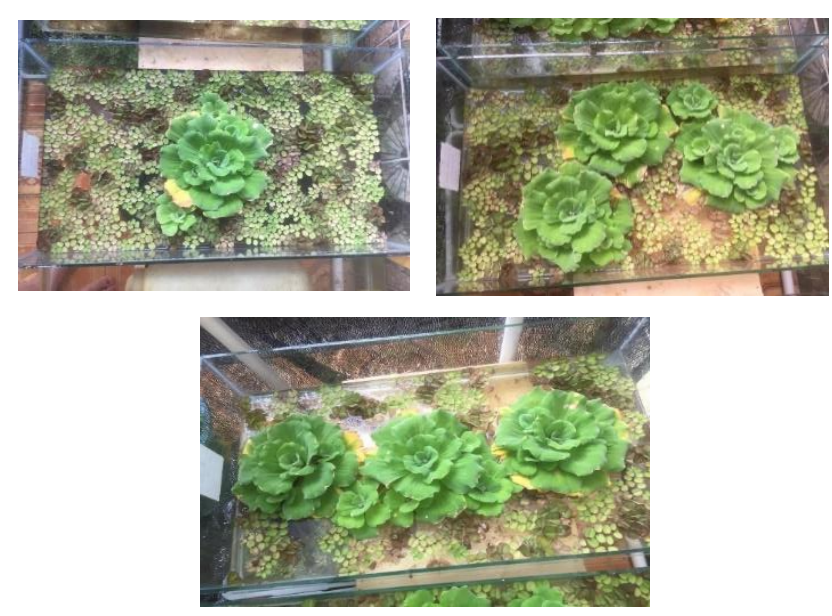

(b) akhir penelitian

Gambar 3 Perbedaan Perubahan Fisik Tanaman pada Awal dan Akhir Penelitian

Pada gambar 3 terjadi perubahan fisik pada kedua tanaman yang dimana tampak jelas kedua tanaman yang digunakan pada awal penelitian berwarna hijau segar dan pada akhir penelitian sebagian dari daun kedua tanaman berubah warna menjadi warna kuning. Berubahnya warna daun pada peneliian ini disebut gejala klorisis dan nekrosis. Penelitan ini sama halnya dengan penelitian yang dilakukan (Oktavia, 2016) pada penelitian tersebut menyatakan terjadinya kerontokan pada daun dan pembusukan, penyebab perubahan pada tanaman karena pencemar telah diserap oleh tubuh tanaman dan akan dibuang dengan cara menggugurkan daun yang tua untuk mengurangi kandungan logam pada tanaman, kerontokan pada akar disebabkan karena penurunan metabolisme penyerapan logam secara berlebihan. Penyebab kerusakan yang terjadi pada daun bisa disebabkan karena tanaman mengalami gejala klorosis dan nekrosis. Menurut (Widiarso, 2011; Nurlina, 2016) gejala klorosis dapat terjadi apabila logam berat yang masuk kedalam tanaman berlebih yang menyebabkan penghambatan enzim pada proses klorofil pada tanaman, sedangkan gejala nekrosis terjadi karena tanaman mengalami kematian pada sel tanaman yang menyebabkan timbulnya kerusakan tanaman seperti bercak pada daun tanaman. Perubahan fisik pada tanaman selaras dengan penelitian yang dilakukan (Nurfitriani, 2019) dalam menurunkan timbal (Pb) dimana pada tanaman kiapu (Pistia stratiotes L) dimana tanaman tersebut mengami gejala klorosis yaitu terjadi perubahan pada daun dengan cara menguning kemudian mati.

\section{B. Efisiensi Tanaman Kayu Apu (Pistia stratiotes L) Dan Kiambang (Salvinia molesta M) Terhadap Penyisihan Besi (Fe) \\ Efisiensi penyisihan besi (Fe)} menggunakan variasi kombinasi tanaman kiambang (Salvinia molesta M) dan tanaman kayu apu (Pistia stratiotes $L$ ) pada reaktor kontrol, reaktor 1,2 dan reaktor 3 dapat dilihat pada Gambar 4.

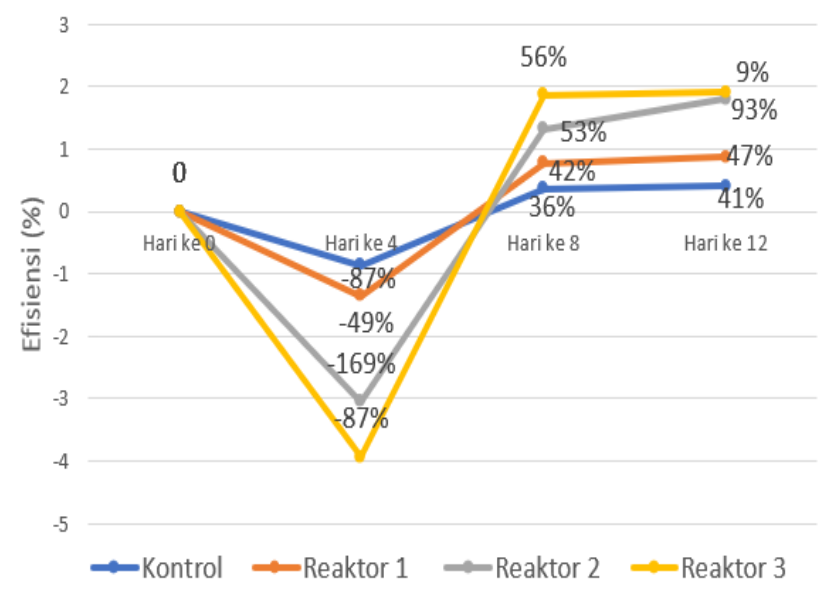

Gambar 4 Efisiensi (\%) Tanaman Kayu Apu (Pistia Stratiotes L) dan Kiambang (Salvinia Molesta M) terhadap Penyisihan Besi (Fe)

Berdasarkan dari hasil analisa pada Gambar 4 efisiensi yang didapat menggunakan kedua tanaman terhadap penyisihan besi $(\mathrm{Fe})$ 
mengalami penurunan efisiensi sebesar $-87 \%$ pada kontrol, dan - 49\%, - 169\%, - 87\% pada reaktor 1, 2 dan reaktor 3 pada pengambilan $\mathrm{H}_{4}$. Terjadinya penurunan efisiensi karena naiknya konsentrasi besi (Fe) yang disebabkan kejenuhan pada tanaman. Terjadi kejenuhan pada $\mathrm{H}_{4}$ dapat disebakan karena tanaman melakukan penyerapan secara berlebihan sehingga tanaman tidak memiliki kemampuan dan melepaskan kontaminan yang telah diserap ke lingkungan sehingga konsentrasi pada hari tersebut menjadi naik. Apabila tumbuhan telah mencapai batas titik jenuh maka penyerapan selanjutnya akan lebih lambat dari sebelum tanaman mangalami titik jenuh. Sedangkan pada $\mathrm{H}_{8}$ sampai $\mathrm{H}_{12}$ dimana efisiensi penyerapan besi (Fe) mengalami kenaikan hal ini karena pada proses removal besi mengalami penurunan yang artinya kedua tanaman yang digunakan telah melewati titik jenuh sehingga terjadi penyerapan besi ( $\mathrm{Fe}$ ) oleh jaringan tumbuhan dan menyebabkan konsentrasi besi (Fe) mengalami penurunan. Terjadinya kejenuhan pada tanaman pada penelitian ini sesuai dengan penelitian yang dilakukan (Nurfitri, 2010) menyatakan pada penelitian yang dilakukan selama 20 hari dalam menurunkan logam berat $\mathrm{Cu}$ menggunakan 3 reaktor terdapat titik jenuh. Titik jenuh terjadi pada hari ke 5, 10 dan 20. Selain itu terjadi kejenuhan pada saat penelitian sama dengan peneliitian yang dilakukan (Permadi, 2019) yaitu pada proses fitoremediasi menggunakan bambu air untuk menurunkan timbal $(\mathrm{Pb})$. Pada penelitian tersebut terjadi penurunan efisiensi sebanyak $-100 \%$ terjadi pada hari ke 9 dan pada hari ke 12. Penyebab turunnya efisiensi tersebut karena pada saat meremoval timbal $(\mathrm{Pb})$ tanaman mengalmiki kejenuhan, kejenuhan tersebut menyebabkan tanaman melepas kembali logam berat yang telah diserap kelingkungan.

Selanjutnya dari hasil pengamatan yang dilakukan efisiensi penyisihan besi ( $\mathrm{Fe}$ ) pada air tanah mengalami kenaikan. Kenaikan efisiensi terjadi pada $\mathrm{H}_{8}$ dan $\mathrm{H}_{12}$. Pada $\mathrm{H}_{8}$ efisiensi penyisihan sebesar $36 \%$ pada kontrol $42 \%, 53 \%, 56 \%$ pada rea'ktor 1,2 dan 3. Kenaikan efesiensi besi (Fe) terus terjadi sampai akhir penelitian, pada $\mathrm{H}_{12}$ efisiensi penyisihan besi (Fe) yang didapatkan sebesar $41 \%$ pada kontrol 47\%, 93\%, 9\%, pada reaktor 1,2 dan reaktor 3 . Terjadinya kenaikan efesiensi penyisihan besi ( $\mathrm{Fe}$ ) karena terjadinya penurunan konsentrasi pada besi
(Fe) yang diserap oleh tanaman. Kenaikan efisiensi penyisihan besi ( $\mathrm{Fe}$ ) pada saat proses fitoremediasi terjadi pada penilitian yang dilakukan (Oktavia, 2016) pada pengolahan limbah cair home industry batik dalam menurunkan kadmium (Cd). Efisiensi penyisihan kadmium (Cd) yang dilakukan selama 9 hari sebesar 58,80\% pada kelompok perlakuan. Penurunan efisiensi pada logam berat $\mathrm{Cd}$ karena telah diserap oleh akar tanaman.

Efisiensi besi $(\mathrm{Fe})$ tertinggi pada penelitian ini terjadi pada reaktor 2 yaitu sebesar 93\% pada $\mathrm{H}_{12}$. Penelitian ini sama halnya dengan penelitian yang dilakukan (Nurfitriani, 2019) dalam meremoval timbal $(\mathrm{Pb})$ didapatkan efisiensi sebesar 93,1\% pada hari ke 8. Selain itu sesuai dengan yang dilakukan (Pribadi, 2016) dalam menyisihkan amoniak pada limbah cair domestik dengan sistem kontinyu, efisiensi yang didapatkan sebesar $75 \%$ dan 97\% pada hari ke 9 dengan menggunakan tanaman kiambang.

\section{Analisa Perbedaan Variasi Kombinasi Tanaman Kayu Apu (Pistia stratiotes $L$ ) dan Kiambang (Salvinia molesta M) Terhadap Penyisihan Besi (Fe)}

Setelah dilakukan penelitian, hasil data yang diperoleh dilakukan uji statistik yaitu menggunakan uji Kruskal Wallis, uji ini dapat untuk mengetahui perbedaan rata - rata pada sampel lebih dari dua kelompok. Uji Kruskal Wallis pada penelitian ini dapat ditunjukkan Tabel 1.

Tabel 1 Hasil Uji Statistik terhadap Removal Besi (Fe)

\begin{tabular}{cllll}
\hline & $\mathbf{F e ~ \mathbf { H } _ { \mathbf { 0 } }}$ & $\mathbf{F e H}_{\mathbf{4}}$ & $\mathbf{F e H}_{\mathbf{8}}$ & $\mathbf{F e H}_{\mathbf{1 2}}$ \\
\hline Chi-Square &, 000 & 5,777 & 6,452 & 5,425 \\
\hline Df & 3 & 3 & 3 & 3 \\
\hline Asymp.Sig. & 1,000 &, 123 &, 092 &, 143 \\
\hline
\end{tabular}

Berdasarkan dari data yang diperoleh pada Tabel 1 nilai signifikan yang didapat pada p-value yaitu, 1.000 pada (Fe H0), 0.123 pada (Fe H4), .092 pada (Fe H8), 0.143 pada (Fe H12) hasil tersebut $>0,05$ yang dimana hasil tersebut melebihi nilai signifikan maka HO diterima atau tidak terdapat perbedaan yang nyata pada removal besi (Fe) menggunakan tanaman (Salvinia molesta $M$ ) dan kayu apu (Pistia stratiotes L).

Penelitian ini memiliki kesamaan dengan penelitian yang dilakukan (Permadi, 
2019) yang dimana hasil p-value sebesar 0,701 yang artinya melebihi 0,05 . Sehingga dari penelitian yang telah dilakukan tidak ada perbedaan dalam meremoval timbal $(\mathrm{Pb})$ menggunakan bambu air.

\section{KESIMPULAN}

Berdasarkan hasil penelitian kedua tanaman yang digunakan mampu menurunkan besi (Fe) pada air tanah. Walaupun pada $\mathrm{H}_{4}$ tanaman mengalami kejenuhan akan tetapi pada $\mathrm{H}_{8}-\mathrm{H}_{12}$ kedua tanaman mampu melewati titik jenuh tersebut. Hal ini dapat disimpulkan bahwa kedua tanaman dapat digunakan untuk meremoval logam berat yang ada pada air. Nilai efisiensi tertinggi pada penurunan konsentrasi Besi (Fe) pada air tanah menggunakan variasi kombinasi kedua tanaman terdapat pada kelompok perlakuan reaktor 2 yaitu sebesar $93 \%$ pada $\mathrm{H}_{12}$. Berdasarkan hasil uji statistik Kruskal Wallis dalam penelitian ini tidak ada perbedaan dalam meremoval besi (Fe) menggunakan tanaman (Salvinia molesta M) dan tanaman kayu apu (Pistia stratiotes L). Melihat dari hasil penelitian ini sebaiknya pada penelitian selanjutnya menambahkan range dari variasi kombinasi tanaman yang digunakan dan variasi lama waktu tinggal.

\section{DAFTAR PUSTAKA}

Ahmadlia, D. R. (2012). Pengaruh Luas Penutupan Kayu Apu (Pistia Stratiotes L) Terhadap Kualitas Kimia dan Fisika pada Berbagai Konsentrasi Limbah Cair Tahu. Universitas Islam Negeri Maulana Malik Ibrahim .

Arasy, S. E. (2016). Penyisihan Kontaminan Pbmenggunakan Typha Latifolia Dengan Metode Sub-Survace Flow Canstructed Wetland. Universitas Riau, Jom Fteknik Vol 3 No1.

Bonny, L. I. (2017). Kemampuan Kayu Apu (Pistia Stratiotes L) dalam Meremediasi Air Tercemar Logam Berat $(\mathrm{Fe})$. Universitas Atma Jaya Yogyakarta.

Lbn-Lipi. (1981 ). Tumbuhan Air. Biologi Nasional Lipi Bogor.

Nurfitri, I. R. (2010). Pengaruh Kerapatan Tanaman Kiapu (Pistia Staratiotes L) Terhadap Serapan Logam $\mathrm{Cu}$ pada
Air. Institut Teknologi Bandung, Volume 16 No 1.

Nurfitriani, F. (2019). Fitoremediasi Air Tercemar Timbal $(\mathrm{Pb})$ Menggunakan Tanaman Apu-Apu (Pistia Stratioes) dengan Sistem Kontinyu. Universitas Islam Negeri Sunan Ampel Surabaya.

Nurlina, S. S. (2016). Akumulasi Logam Berat Besi (Fe) pada Kiapu Pistia Stratiotes L dari Air Sumur Sekitar Workshop Unhas. Universitas Hasanuddin Makasar, Isbn: 978-60272245-1-3.

Oktavia, B. N. (2016). Pengaruh Variasi Lama Kontak Fitoremediasi Tanaman Kiambang (Salvinia Molesta) Terhadap Kadar Kadmium (Cd) pada Limbah Cair Home Industry Batik X Magelang. Universitas Diponegoro Semarang, Vol 4 No 5 Issn 23563346.

Permadi, M. I. (2019). Pemanfaatan Bambu Air (Equisetum Sp.) Untuk Menurunkan Kadar Timbal $(\mathrm{Pb})$ Menggunakan Fitoremediasi Sistem Batch. Universitas Islam Negeri Sunan Ampel Surabaya.

Pribadi, B. Z. (2016). Pengaruh Luas Penutupan Kiambang (Salvinia Molesta) Terhadap Penurunan COD, Amonia, Nitrit, dan Nitrat pada Limbah Cair Domestik (Grey Water) dengan Sistem Kontinyu. Universitas Diponegoro, Volume 5 No 4 .

Rido, R. L. (2013). Penggunaan Tanaman Kayu Apu (Pistia Stratiotes) Untuk Pengolahan Air Limbah Laundry Secara Fitoremediasi. Universitas Pembangunan Nasional Veteran Jatim, Jurnal Ilmiah Teknik Lingkungan Vol 5 No 2.

Said, N. I. (2005). Metode Penghilangan Zat Besi dan Mangan didalam Penyediaan Air Minum Domestik. Pusat Pengkajian dan Penerapan Teknologi Lingkungan, BPPT , Vol 1 No3.

Sata, Y. S. (2018). Efektifitas Kombinasi Kiambang (Salvinia Adnatas Desv) dan Kayu Apu (Pistia Stratiotes L.) dalam Fitoremediasi Logam 
Kadmium (Cd) di Perairan.

Universitas Pakuan.

Supiyanti, H. E. (2015). Kandungan Logam

Berat Besi (Fe) pada Air, Sedimen, dan Kerang Hijau (Perna Viridis) diperairan Tanjung Emas Semarang. Jurnal Kelautan Tropis, Vol. $18(1): 38-45$.

Widiarso, T. (2011). Fitoremediasi Air Terkontaminasi Nikel dengan Menggunakan Tanaman Ki Ambang (Salvinia Molesta). Institut Teknologi Sepuluh November, Skripsi.

Yuliani. (2019). Fitoremediasi Limbah Pelumas Bekas Menggunakan Tanaman Eceng Gondok (Eichhornia Crassipes) dengan Variasi Penambahan Pupuk. Universitas Islam Negeri Sunan Ampel Surabaya. 